\title{
Low Carbon Cooling Approach for the Residences in the UAE: A Case Study in Dubai
}

\author{
Basim Touqan ${ }^{1}$, Hanan Taleb ${ }^{2}$, Muna Salameh ${ }^{1,3}$ \\ ${ }^{1}$ Architecture and Sustainable Built Environment, British University in Dubai \\ UAE \\ 2014239094@student.buid.ac.ae2014139085@student.buid.ac.ae \\ ${ }^{2}$ Sustainable Design of Built Environment, British University in Dubai \\ $\mathrm{UAE}$ \\ hanan.taleb@buid.ac.ae \\ ${ }^{3}$ Ajman University \\ UAE
}

\begin{abstract}
Prior to the discovery of electrical power, the buildings in the UAE were built with a concentration on the passive designs in order to have daylight and natural ventilation as well as avoiding the undesired heat. The wind tower was considered as the most familiar cooling strategy followed in the traditional architecture. However, the advanced air conditioning systems of the present time have removed the need for the wind catchers since the indoor comfort could not be achieved enough by the wind towers and at the same level that advanced air conditioning systems can do. Despite the integration of the Green Buildings in UAE, the cheap energy prices and the poor attention to energy efficiency buildings have converted UAE to one of the top ten countries worldwide that have high electricity consumption per capita. This work offers a low carbon proposal to solve the problem and demonstrates three strategies that can be adopted in UAE to implement energy efficient buildings without compromising on the indoor comfort and air quality. IES VE and RETScreen software were used to simulate and analyse the proposed strategies. Using proper wall construction material that has minimum thermal transmittance value is one of the strategies that can be implemented to reduce the air-conditioning operating time thus less energy consumption. In addition to its benefits to the urban area, Green Roof is the second strategy that can be also implemented in order to reduce the thermal transmittance value of the roof. The last strategy is to employ Photovoltaic Panels to produce clean energy and to reduce the reliance on the fossil oil-generated power. As an overall, the bundle of three strategies has proved its efficiency to reduce the cooling energy consumption. The total electricity saving was $15.45(\mathrm{MWh})$ and with a percentage of $19.6 \%$ of the total base case cooling power consumption.
\end{abstract}

Keywords: Sustainability, Passive Cooling Strategies, Thermal Gain, Indoor Comfort, Energy Efficiency, UAE

\section{Introduction}

The cooling approach in the past was focusing on keeping off the sun and using special stonework that has thermal inertia. In the hot and arid areas like UAE, the design, and the shape of the house in the past was dominated by the need for cooling and fresh air [1]. The buildings in UAE were built using the passive designs in order obtain ventilation and enough daylight with minimum heat from outdoors. Courtyards, least windows areas [2] and wind catchers [3] were a couple of passive cooling approaches used in UAE. Over the time, cooling methods have been developed significantly. The integration of effective air conditioning system started to show up only in the 1960s [1]. The main cooling methods used in the current time in UAE are the air condition systems employing advanced mechanical cooling technologies which led to eliminating some significant social and climatic architectural features such as courtyards and wind catchers so that they have been neglected in the new housing designs [4].

Problem Statement: The recent building design in Dubai has been impacted widely by the western urban designs. The facade with glazing was extensively used which significantly increased the rate of thermal gain inside the buildings. The insufficient building's insulation and the more exposure to sun radiation resulted in more heat gains, thus more cooling energy consumption. On top of that, the energy prices in the region are cheap; this current overall situation has encouraged the integration of cooling systems that featured with high energy consumption. Although Dubai government has adopted 
recently environmental related policies to be in line with the international energy key performance indicators [5], UAE still one of the top ten countries that have high electricity consumption per capita [6].

The Aim of the study: The building sector, in general, is a major contributor to high carbon dioxide emissions [7]. Along with lighting, HVAC system is the biggest energy consumer in the sector. It indeed consumes around 50\% of the total energy consumed by buildings [8]. This study aims to test some strategies that can be implemented on a residence in Dubai to reduce the energy consumed by Air Condition system and to reach energy efficient Buildings.

Case Study: UAE is an area of hot and arid climate; it is too hot and dry in summer accompanied by the very high temperature that reaches $48 \mathrm{C}^{\circ}$ at coastal cities. However; cold months in UAE commence on end of December to late February. The case study selected for the research is a Villa located in Dubai Silicon Oasis in Dubai; it is an area which characterized as modern urban consists of a combination of tower buildings as well as Villas complexes.

\section{Literature Review}

Energy efficiency is the philosophy of using least energy to have the same service and without compromising on the quality and comfort. On one hand, passive approaches were focusing on methodologies of using natural elements and smart design ideas which result indirectly to achieve energy efficiency. On the other hand, finding alternatives for fossil oil energy, such as solar, wind hydro and biomass energy, etc., is being approached too. Within this context, many researchers have been working on the passive and active strategies aiming to achieve energy saving.

\subsection{Passive cooling strategies}

As HVAC consumes 50\% of the total energy in a building [8], finding smart solutions related to cooling or heating strategies that consume less energy became a core interest of researchers worked in the field of energy efficiency, for example, green roof has been investigated in [9] and found that it is able to achieve power saving by optimizing the thermal performance in the building and able to reduce the internal temperature in the range of $2.3 \mathrm{C}^{\circ}$. For other building design aspect, the study in [10] has focused on the impact of shading devices, namely external screen and louvers and proved that such strategies are able to achieve energy saving. Other researchers like [11] have addressed multiple cooling techniques and studied a typical Saudi residential building by comparing the impact of insulation of the roofs and walls with the glazing and external shading on the energy consumption; they proved that less thermal transmittance (U-value) through walls and roofs can reduce the cooling or heating power energy. Some other researchers worked more widely by investigating extra techniques, in addition to the shading devices, glazing types, insulation of the roof and walls and thickness of the external walls, smart manipulation of window ratio to the wall and orientation of the window are also investigated in [12], the researchers have verified that such strategies have significant impact on reducing the thermal load. [5]was different than the others by proposing shading, glazing, wind towers, natural ventilation, evaporative cooling, insulation and green roof as cooling techniques in hot UAE, the author was able to prove a 9\% reduction in cooling load so that the annual energy consumption can be reduced in the range of $23.6 \%$. On top of all mentioned papers, there was an interesting study in [13] pertaining to an innovative idea that is different than the others' approach, the PV panel that generates clean energy can be used also as a shading device and double the benefits.

\subsection{Active Strategies}

In hot areas like UAE, passive cooling techniques during summer time might be not sufficient, so that operating active cooling devices are also important to achieve completely indoor comfort. Active cooling devices are a cooling application that consumes energy in order to cool the indoor spaces; those are for example mechanical cooling devices such as fans and air conditioning and consume a lot of energy and impact negatively the environment and the wallet alike, however, this impact can be significantly mitigated when such mechanical cooling device operate smartly and when it is needed only. A solution has been proposed in [14] by using a control theory to establish the intelligent building concept, the study has identified a comfort parameters matrix against which the energy consumption has been controlled so that balance between the indoor comfort and the energy consumption has been achieved. Nonetheless; in terms of energy efficiency, using active cooling techniques is not helpful if it is implemented with the absence of passive construction techniques, this has been emphasized by [15]. According to the fact that passive techniques might not be enough to cool the indoor spaces and the mechanical cooling is an important device to achieve indoor thermal comfort, this paper comes to pursue a hybrid approach by implementing two passive cooling strategies which are namely increasing the insulation in the external walls 
of the building and integration the Green Roof, in addition to that, active strategy will also be employed, that is basically integration a PV panel to generate clean energy.

\section{Research methodology}

This study incorporates investigatory methodology using IES VE software (Integral Environmental Solution - Virtual Environment) that will be used to configure the building model, simulate and assess the impact of two improvement strategies, namely the insulated external walls and the green roof on the energy efficiency. The model and simulation results including the energy consumption will be validated and compared with a reference energy consumption standardized by Dubai guide [16] in which it estimates that every person in Dubai consumes 20 (MWh) per year, consequently, a villa accommodating 6 people plus house maid consume140 (MWh). Table 1 shows 145 MWh as total electricity that can be consumed per year in Villa of the case study simulated by IES so that the difference from Dubai guide is $4.1 \%$ only.

Table 1: Electricity consumed in the Villa per year simulated by IES.

\begin{tabular}{|c|c|c|c|c|c|c|c|c|c|c|c|c|c|}
\hline Date & $\begin{array}{l}\text { Jan 01- } \\
31\end{array}$ & $\begin{array}{l}\text { Feb 01- } \\
28\end{array}$ & $\begin{array}{l}\text { Mar } \\
01-31\end{array}$ & $\begin{array}{l}\text { Apr 01- } \\
30\end{array}$ & $\begin{array}{l}\text { May } \\
01-31\end{array}$ & $\begin{array}{l}\text { Jul } \\
01-30\end{array}$ & $\begin{array}{l}\text { Jul } \\
01-31\end{array}$ & $\begin{array}{l}\text { Aug } \\
01-31\end{array}$ & $\begin{array}{l}\text { Sep 01- } \\
30\end{array}$ & $\begin{array}{l}\text { Oct 01- } \\
31\end{array}$ & $\begin{array}{l}\text { Nov } \\
01-30\end{array}$ & $\begin{array}{l}\text { Dec 01- } \\
31\end{array}$ & Total \\
\hline MWh & 4.34 & 5.29 & 7.57 & 11.23 & 15.85 & 17.24 & 19.23 & 19.52 & 16.84 & 13.72 & 9.33 & 5.73 & 145.9 \\
\hline
\end{tabular}

According to [5], 5\% is considered as a maximum discrepancy, therefore, it can be easily decided that the model built by IES is valid and the further simulation results and analysis will be reliable. Last, of all, PV panels is the third strategy, RETScreen software will be used to calculate the energy that can be generated from the PV panels and to analyze how much they can contribute to energy efficiency. In the meanwhile, the building regulations of Estidama produced by the Abu Dhabi Urban Planning Council (DUP) are used as a reference to be compared with the U-values that can be obtained from applying insulation in the external walls. 1 Pearl is a requirement of Estidama that stipulates maximum thermal transmittance value (U-value) of $0.32 \mathrm{~W} / \mathrm{m}^{2} \mathrm{~K}$ to consider a wall well insulated.

\section{Results}

\subsection{Insulation in the external wall}

Base case: The external wall was configured and simulated by IES software with U-value of $1.6519 \mathrm{~W} / \mathrm{m}^{2} \mathrm{~K}$. The specifications of the wall were quoted from the engineering drawings obtained from the company developed the Villa. As per 1 Pearl - Estidama requirement, the wall is not insulated enough. Meanwhile, the monthly chiller energy consumption of base case is displayed in table 2. The peak consumption can be witnessed in the month of August with total value of $11.95(\mathrm{MWh})$ while the total chiller energy consumption per year is $78.56(\mathrm{MWh})$

Table 2: Total chiller energy consumption per year - base case.

\begin{tabular}{|l|l|l|l|l|l|l|l|l|l|l|l|l|}
\hline Date & Jan 01- & Feb 01- & Mar & Apr 01- & May & Jun & Jul & Aug & Sep 01- & Oct 01- & Nov \\
& 31 & 28 & $01-31$ & 30 & $01-31$ & $01-30$ & $01-31$ & $01-31$ & 30 & $\begin{array}{l}\text { Dec 01- } \\
31\end{array}$ & Total \\
& 31 & 1.6603 & 3.1056 & 5.8915 & 9.2299 & 10.340 & 11.734 & 11.952 & 10.048 & 7.6513 & 4.4836 & 1.7433 \\
\hline MWh & 0.7217 & $\mathbf{7 8 . 5 6}$ \\
\hline
\end{tabular}

On the other hand, the sensible cooling load in a room by selecting August as the hottest month of the year in UAE is illustrated in figure (1) which shows that the typical sensible cooling peak loads are in the range of $60-80 \mathrm{~kW}$.

Efficient case: Polyurethane has been successfully used by [17] as an additional insulation layer in the external walls. Using the IES VE software, polyurethane board of $6.3 \mathrm{~cm}$ thickness layer is also used and added to the original configuration of the base case. The U-value has been significantly reduced to $0.32 \mathrm{~W} / \mathrm{m}^{2} \mathrm{~K}$. This value absolutely fulfills 1 Pearl of Estidama. Nevertheless, the monthly chiller energy consumption based on the efficient case external wall configuration is displayed in table 3. The peak consumption in August is reduced to 10.57 (MWh) while the total chiller energy consumption per year is reduced to 71.58 (MWh) 


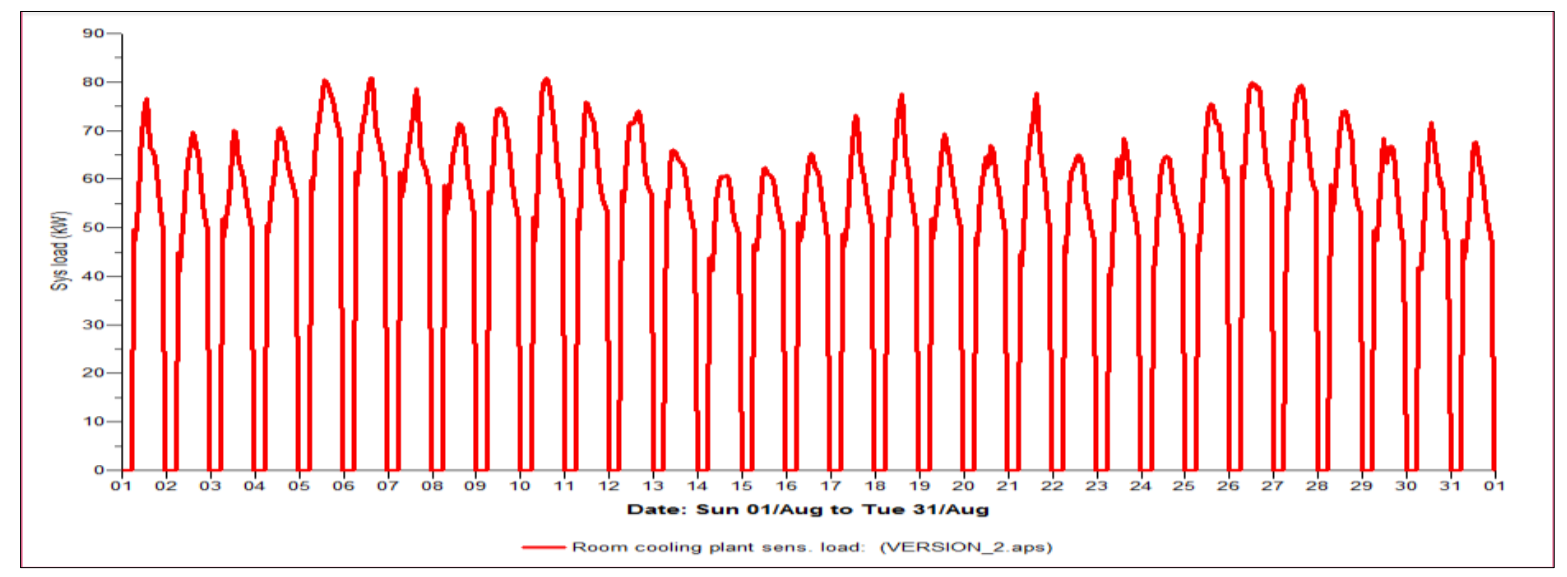

Fig. 1: Room cooling plant sensible load- base case.

Table 3: Total chiller energy consumption per year - efficient case.

\begin{tabular}{|l|l|l|l|l|l|l|l|l|l|l|l|l|l|}
\hline Date & Jan 01- & Feb 01- & Mar & Apr 01- & May & Jul & Jul & Aug & Sep 01- & Oct 01- & Nov & Dec 01- & Total \\
& 31 & 28 & $01-31$ & 30 & $01-31$ & $01-30$ & $01-31$ & $01-31$ & 30 & 31 & $01-30$ & 31 & \\
\hline MWh & 0.9173 & 1.7584 & 3.0124 & 5.4121 & 8.2869 & 9.1955 & 10.393 & 10.577 & 8.9377 & 6.9461 & 4.2444 & 1.8984 & $\mathbf{7 1 . 5 8}$ \\
\hline
\end{tabular}

Similarly, the sensible cooling peak loads in August for a room in the Villa (figure 2) are reduced to the range of 55 $75 \mathrm{~kW}$.

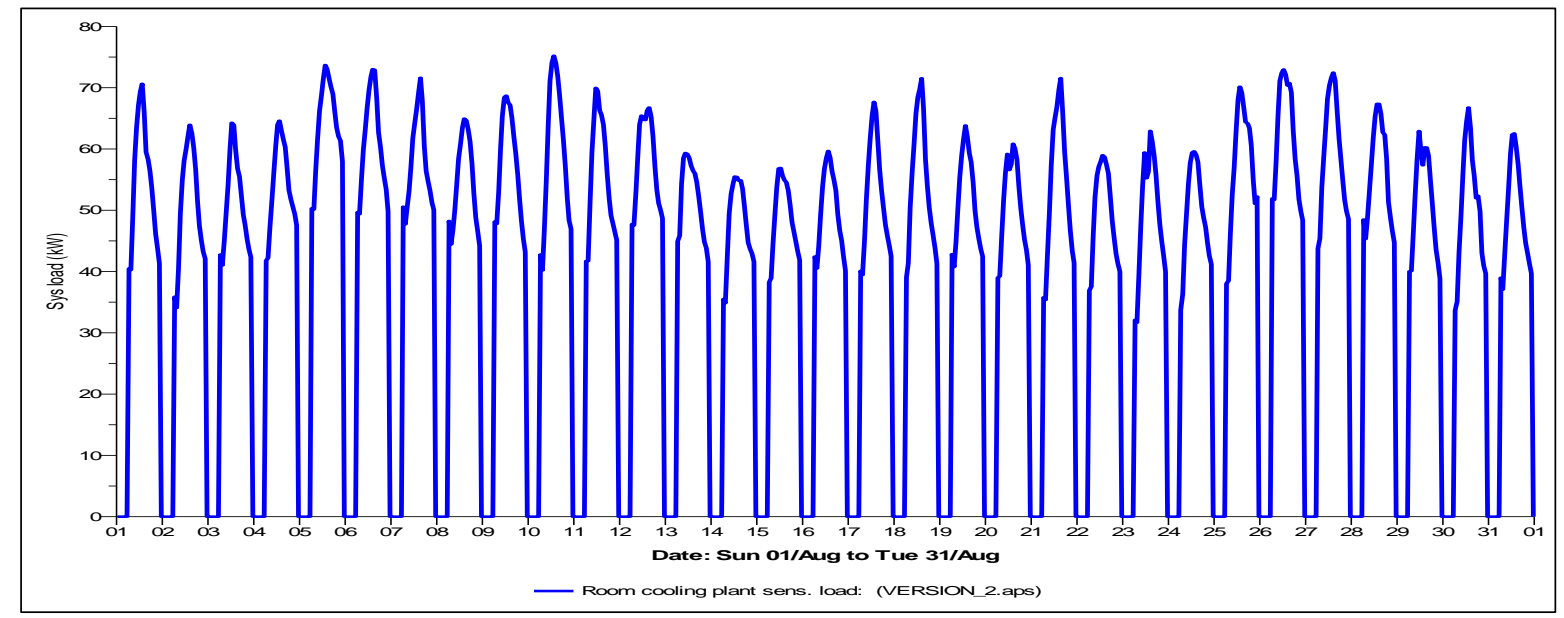

Fig. 2: Cooling sensible load during the hottest month of August.

\subsection{Green Roof}

Green Roof is the second passive strategy that is used to achieve energy consumption reduction; the green roof is used in this case as roof insulation method. As per the studies related to the external heat gain, it has been concluded that the roof is the main access for the heat gain from the sun radiation. In addition to the main role that green roof plays in the energy consumption, it can also be effective in reducing the heat island effect and in reducing the microclimate temperature within the urban environment [5]. 
Plane Roof: In the same way, the plane roof is configured and simulated using IES VE software, the configuration of the plane roof produces U-value of $0.4812 \mathrm{~W} / \mathrm{m}^{2} \mathrm{~K}$. The plane roof specifications were also quoted from the engineering drawings obtained from the company developed the Villa of the case study. The simulation has considered only for the master bedroom in the Villa so that monthly cooling power consumption for the master bedroom is displayed in table 4. The power consumption peak occurred in the month of August with a value of 3.4 (MWh).

Table 4: Total cooling power consumption - Plane room case.

\begin{tabular}{|l|l|l|l|l|l|l|l|l|l|l|l|l|}
\hline Date & Jan 01- & Feb 01- & Mar & Apr 01- & May & Jul & Jul & Aug & Sep 01- & Oct 01- & Nov \\
& 31 & 28 & $01-31$ & 30 & $01-31$ & $01-30$ & $01-31$ & $01-31$ & 30 & $\begin{array}{l}\text { Dec 01- } \\
31\end{array}$ & Total \\
& 31 & 0.4338 & 0.8372 & 1.6679 & 2.6352 & 2.9584 & 3.3525 & 3.4097 & 2.8456 & 2.1468 & 1.2432 & 0.4482 \\
\hline MWh & 0.1621 & 0.422 .14 \\
\hline
\end{tabular}

In the meanwhile, cooling sensible load during the hottest month of August (figure 3) for the room has reported peak loads of $6.5-8.5 \mathrm{~kW}$.

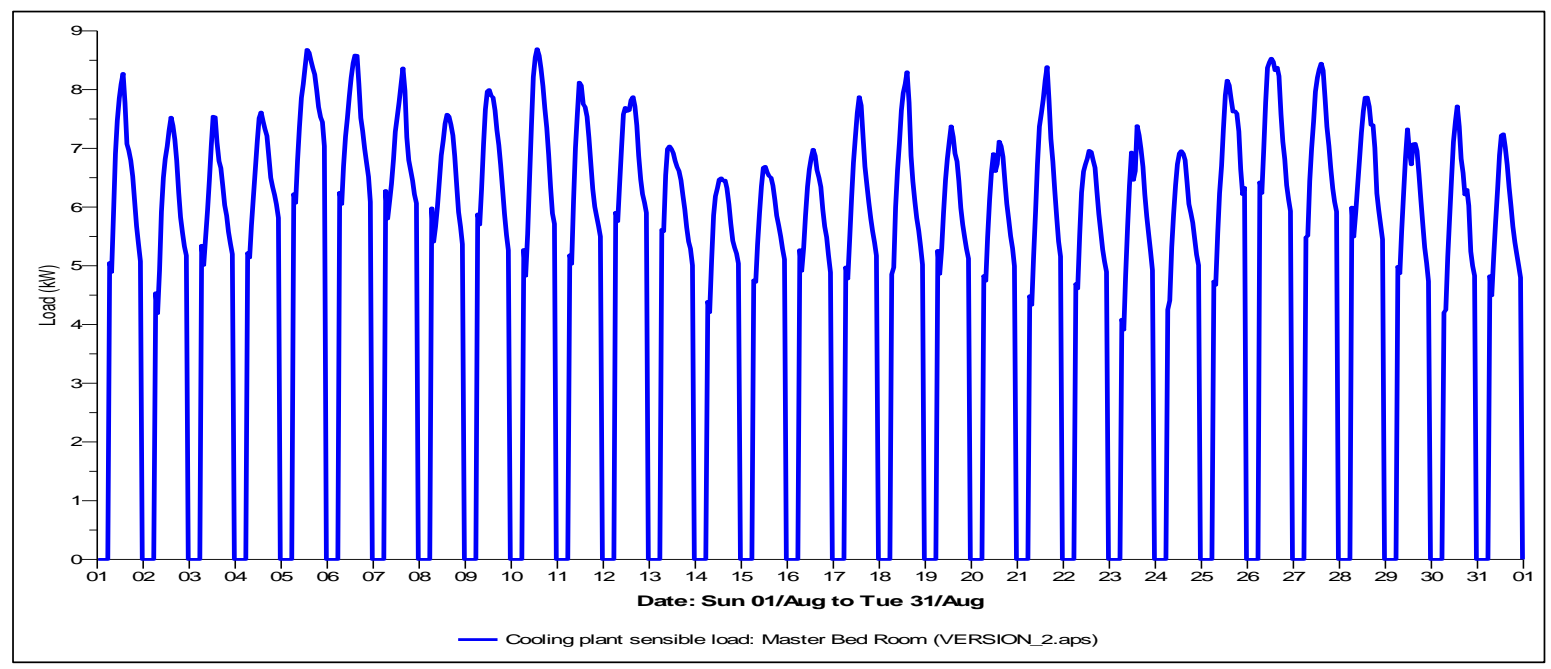

Fig. 3: The cooling plant sensible load during the hottest month of August for the master bedroom based on the plane roof.

Computational Fluid Dynamics (CFD) provided by IES software has been calculated for the master bedroom and the result the plane roof case is shown in figure (6), which will be reviewed in the discussions section.

Green Roof: The green roof model adopted in this study is the same model proposed by [9]; it is composed of the following layers and showed in table 5:

Table 5: Green roof configuration.

\begin{tabular}{|c|c|c|c|c|}
\hline & $\begin{array}{l}\text { Thickness } \\
\text { (m) }\end{array}$ & $\begin{array}{l}\text { Thermal } \\
\text { Conductivity }\end{array}$ & $\begin{array}{l}\text { Resistance = } \\
\text { thickness / }\end{array}$ & $\begin{array}{l}\text { Thermal } \\
\text { Transmittance }\end{array}$ \\
\hline Substrate & 0.08 & 0.27 & 0.3 & 3.33 \\
\hline Drainage and storage & 0.055 & 0.137 & 0.4 & 2.4 \\
\hline Insulation & 0.03 & 0.034 & 0.88 & 1.13 \\
\hline Protection & 0.003 & 0.004 & 0.71 & 1.4 \\
\hline Water Proof & 0.0018 & 0.16 & 0.011 & 90.9 \\
\hline Lightweight Concrete & 0.075 & 0.098 & 0.76 & 1.3 \\
\hline
\end{tabular}

Using the IES VE software, the green roof was configured and simulated above the master bedroom of the Villa, the resulted U-value is $0.1982\left(\mathrm{~W} / \mathrm{m}^{2} . \mathrm{K}\right)$ so that monthly cooling power consumption for the master bedroom is displayed in table 6. The power consumption peak occurred in the month of August reduced to a value of 2.86 (MWh). Furthermore cooling sensible load during the hottest month of August (figure 4) for the room has reduced peak loads to $5.7-7.8 \mathrm{~kW}$. 
Computational Fluid Dynamics (CFD) provided by IES software has been calculated for the master bedroom and the result of the plane roof case is shown in figure (7), which will be reviewed in the discussions section.

Table 6: Total cooling power consumption for - Green Roof case.

\begin{tabular}{|c|c|c|c|c|c|c|c|c|c|c|c|c|c|}
\hline Date & $\begin{array}{c}\text { Jan 01- } \\
31\end{array}$ & $\begin{array}{c}\text { Feb 01- } \\
28\end{array}$ & $\begin{array}{c}\text { Mar } \\
01-31\end{array}$ & $\begin{array}{c}\text { Apr 01- } \\
30\end{array}$ & $\begin{array}{l}\text { May } \\
01-31\end{array}$ & $\begin{array}{c}\text { Jul } \\
01-30\end{array}$ & $\begin{array}{c}\text { Jul } \\
01-31\end{array}$ & $\begin{array}{c}\text { Aug } \\
01-31\end{array}$ & $\begin{array}{c}\text { Sep 01- } \\
30\end{array}$ & $\begin{array}{c}\text { Oct } 01- \\
31\end{array}$ & $\begin{array}{c}\text { Nov } \\
01-30\end{array}$ & $\begin{array}{c}\text { Dec 01- } \\
31\end{array}$ & \\
\hline MWh & 0.2196 & 0.446 & 0.7767 & 1.4587 & 2.2496 & 2.4963 & 2.8164 & 2.8633 & 2.4042 & 1.8576 & 1.1312 & 0.4886 & 9.208 \\
\hline
\end{tabular}

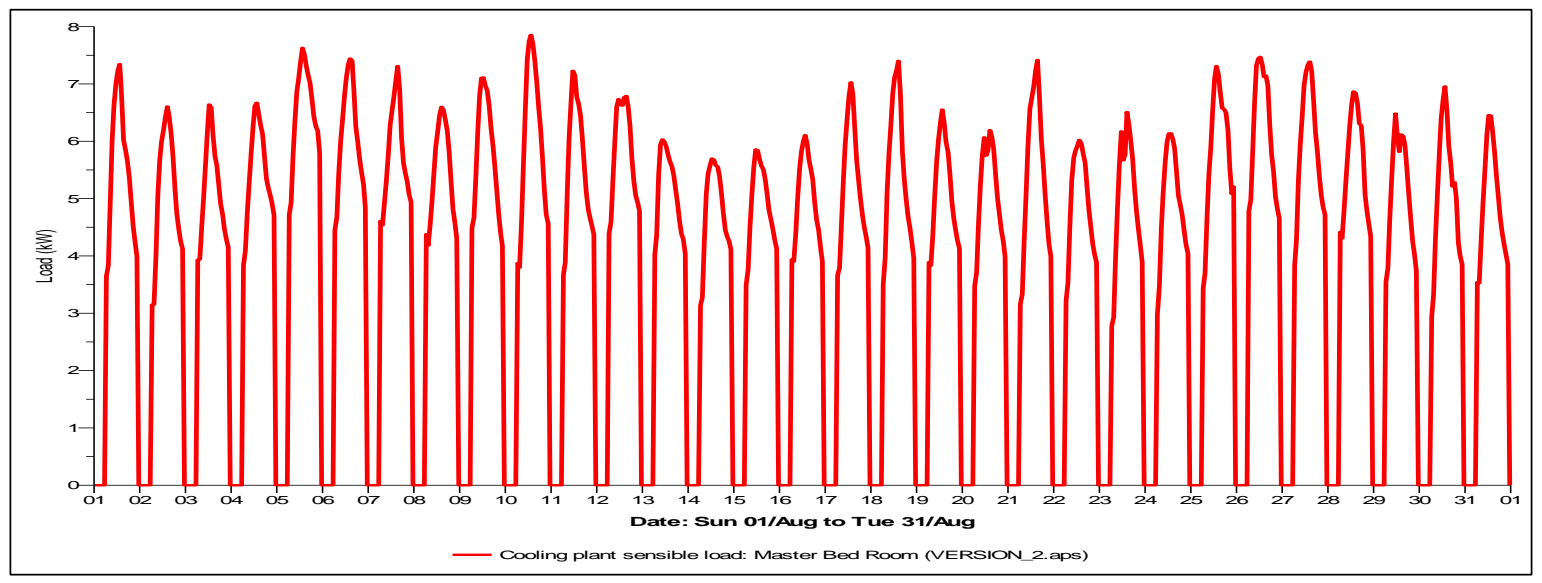

Fig.4: The cooling plant sensible load during the hottest month of August for the master bedroom hased on the Green Roof

\subsection{Integration of PV Panels in the Villa}

Dubai has initiated Net metering policy on 2015 to encourage the deployment of renewable energy in the emirate, by this policy, Dubai is aiming to have 7\% of power supply from renewable energy by 2020 and $15 \%$ by 2030 [18]. Therefore the third strategy in this research is installing PV panels on the roof of the Villa that contributes with $15 \%$ of the total electricity consumed by the Villa to fulfill the 2030 target. Going back to (table 1), the value of the power consumption in the Villa is $146(\mathrm{MWh})$ so certain number of PV grid connected systems that generate power equal to 22 (MWh) (15\% of the $146(\mathrm{MWh})$ ) can be installed. Figure (5) shows the selection and calculation of the PV panels in terms of a number of units and the total electricity they can generate. 53 units type poly-Si each with a power capacity of 12.99 and occupying 87 meters squared have been selected. The calculation has been obtained by using RETScreen software developed by Canadian Government and Dubai's weather profile has been selected as a basis for the calculation.
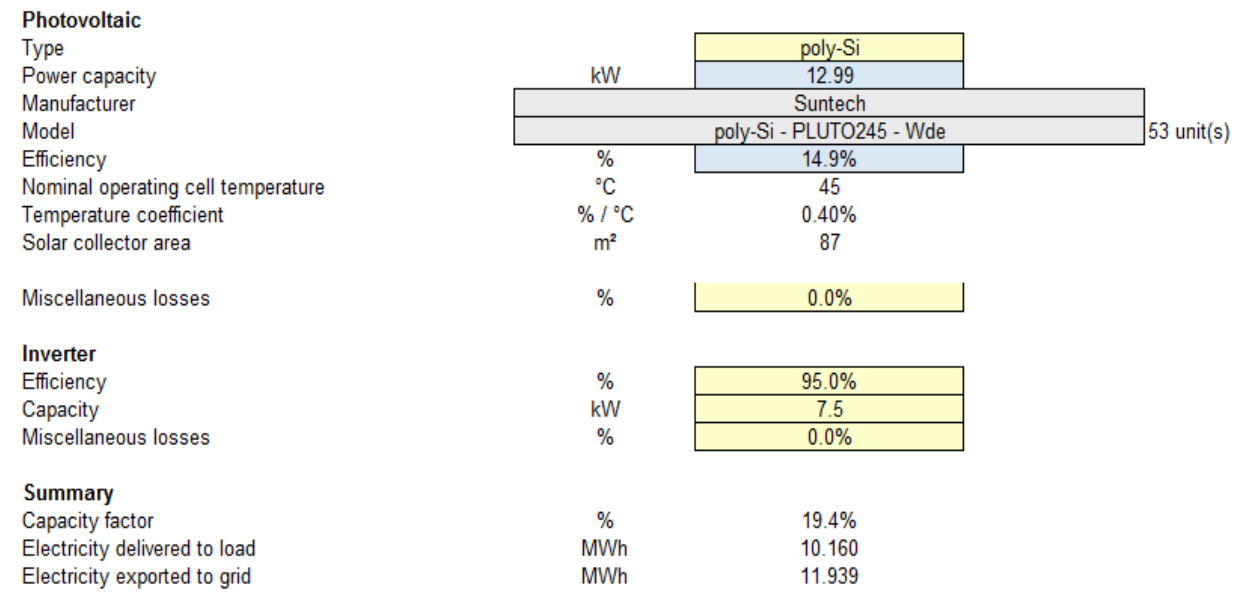

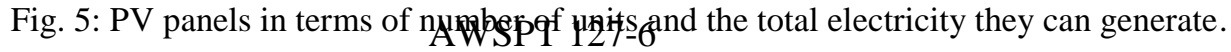


The installed PV grid connected systems has managed to generate total energy of approximately 22 (MWh), 10.16 $(\mathrm{MWh})$ was delivered to the load and $11.94(\mathrm{MWh})$ was exported to the grid.

\section{Results discussions}

By adding the polyurethane board with a thickness of $6.3 \mathrm{~cm}$ to the original wall's layers, the "1 Pearl" requirement of Estidama has been fulfilled, table 7 shows the comparison between the base and the efficient cases.

Table 7: Comparison between the base and the efficient external insulation case.

\begin{tabular}{|c|c|c|}
\hline 0 & Base case & Efficient case \\
\hline Wall configuration & $-\quad$ Perlite Plaster $(2 \mathrm{~cm})$ & $\begin{array}{c}\text { Perlite Plaster }(2 \mathrm{~cm}) \\
\text { Polyurethane Board }(6.3 \mathrm{~cm}) \\
\text { Concrete block }(20 \mathrm{~cm}) \\
\text { Perlite Plaster }(1.5 \mathrm{~cm})\end{array}$ \\
\hline U-value & $-\quad$ Concrete block $(20 \mathrm{~cm})$ & - \\
\hline $\begin{array}{c}\text { Perlite Plaster }(1.5 \mathrm{~cm}) \\
\text { Cooling load during hottest month of } \\
\text { August }\end{array}$ & $-\quad 1.65 \mathrm{~W} / \mathrm{m}^{2} . \mathrm{K}$ & $0.32 \mathrm{~W} / \mathrm{m}^{2} . \mathrm{K}$ \\
\hline
\end{tabular}

With the polyurethane, the transmittance value is reduced from $1.65\left(\mathrm{~W} / \mathrm{m}^{2} . \mathrm{K}\right)$ to $0.32\left(\mathrm{~W} / \mathrm{m}^{2} . \mathrm{K}\right)$ that caused less heat leakage from outside to inside the building, accordingly, cooling load has been also reduced also from the range of peaks $(61 \mathrm{~kW}$ to $82 \mathrm{~kW})$ to the range of peaks $(53 \mathrm{~kW}$ to $75 \mathrm{~kW})$ so that operating time of the AC was shorter. The total annual reduction of chiller energy consumption was from $78.56(\mathrm{MWh})$ to 71.58 (MWh). Consequently, insulation in the external wall as a passive cooling strategy was successful to reduce the cooling power consumption with a value of 6.98 (MWh) and a percentage of $8.8 \%$. In the case of Green Roof, table (8) shows the comparison related to thermal effect between the plane and green roof. Reduction in the thermal transmittance value from $0.4812\left(\mathrm{~W} / \mathrm{m}^{2} . \mathrm{K}\right)$ to $0.1982\left(\mathrm{~W} / \mathrm{m}^{2} . \mathrm{K}\right)$ caused the thermal cooling load to be reduced too from peaks of $(6.5-8.7) \mathrm{kW}$ to $(5.5$ to 7.9$) \mathrm{kW}$ which in turn reflected on reduction on the operating time of the AC, consequently the annual chiller energy consumption has been reduced from 22.14 (MWh) to 19.2 (MWh).The Green Roof implementation was successful to reduce the cooling power consumption in the range of $2.94(\mathrm{MWh})$ which is $13.2 \%$ of total annual cooling energy in the room and $3.7 \%$ of total annual cooling energy in the Villa.

Table 8: Comparison between the plane roof and the green room.

\begin{tabular}{|c|c|c|}
\hline & Plane Roof & Green Roof \\
\hline Roof Configuration & $\begin{array}{cc}- & \text { Gravel }(5 \mathrm{~cm}) \\
- & \text { Polystyrene }(5 \mathrm{~cm}) \\
- & \text { Membrane }(0.4 \mathrm{~cm}) \\
\text { Reinforced Concrete }(25 \mathrm{~cm}) \\
-\quad \text { Plaster (Dense) }(1 \mathrm{~cm})\end{array}$ & $\begin{array}{cc}- & \text { Cultivated Peat Soil 133\%D.W. Moisture }(8 \mathrm{~cm}) \\
- & \text { Gravel-Based Soil }(5.5 \mathrm{~cm}) \\
- & \text { Insulation }(3 \mathrm{~cm}) \\
- & \text { Fibreboard }(0.3 \mathrm{~cm}) \\
- & \text { Roofing Felt }(0.18 \mathrm{~cm}) \\
-\quad \text { LW Concrete } 40 \text { LBS }- \text { HF-C14 }(7.5 \mathrm{~cm}) \\
-\quad \text { Polystyrene }(5 \mathrm{~cm}) \\
-\quad \text { Membrane }(0.4 \mathrm{~cm}) \\
-\quad \text { Reinforced Concrete }(25 \mathrm{~cm}) \\
-\quad \text { Plaster (Dense) }(1 \mathrm{~cm}) \\
\end{array}$ \\
\hline $\mathrm{U}$-value & $0.4812 \mathrm{~W} / \mathrm{m}^{2} . \mathrm{K}$ & $0.1982 \mathrm{~W} / \mathrm{m}^{2} \cdot \mathrm{K}$ \\
\hline $\begin{array}{l}\text { Cooling plant sensible load during } \\
\text { the hottest month of August for the } \\
\text { master bed }\end{array}$ & From $6.5 \mathrm{~kW}$ to $8.7 \mathrm{~kW}$ & From $5.5 \mathrm{~kW}$ to $7.9 \mathrm{~kW}$ \\
\hline $\begin{array}{l}\text { Total annual power consumption for } \\
\text { the master bedroom }\end{array}$ & $22.14(\mathrm{MWh})$ & $19.2(\mathrm{MWh})$ \\
\hline CFD: Temperature in the master & $26 \mathrm{C}^{\circ}$ & $24 \mathrm{C}^{\circ}$ \\
\hline
\end{tabular}


bedroom at 15th August 12:00 PM

The CFD analysis show that the green roof was able to reduce the temperature inside the room with a value of 2 Celsius in comparison with the plane roof; such reduction can be understood as reduction in the cooling load, thus reduction in the operating time of the $\mathrm{AC}$ chiller and reduction in the cooling power consumption, figure (12) and figure (13).

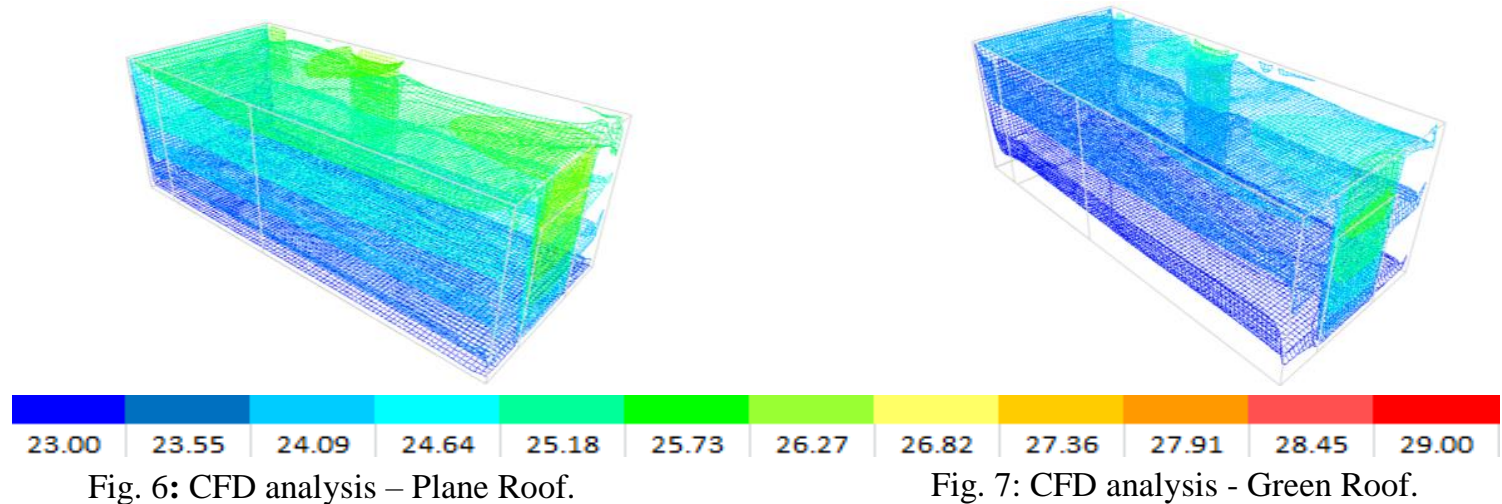

Integration of the PV panel generated electrical power equal to $22.14(\mathrm{MWh})$ which form $15 \%$ of the total annual consumption in the residence, thus clean energy, low carbon emission and fulfilment of Dubai's vision by 2030. Since HVAC system consumes $50 \%$ of total power, the total power generated by the PV and delivered to the load so that 5.08 $(\mathrm{MWh})$ been consumed by the AC system, this value represents $6.4 \%$ of the AC power consumption which can be considered as power saving. As an overall, the bundle of three strategies has proved their efficiency to reduce the cooling energy consumption and to enhance the energy efficiency in the residence. The total power consumption saving was 15.45 $(\mathrm{MWh})$ and with a percentage of $19.6 \%$ of the total cooling power consumption in the Villa

\section{Conclusion}

The buildings in UAE were built before the discovery of electricity with a concentration on the passive designs in order to have daylight and natural ventilation as well as avoiding the undesired heat. The architectural style in the past has characterized UAE which has been developed from the climatic as well as topographical and geographic conditions. For the purpose of natural ventilation, Wind Catchers were used very often in the region in order to mitigate the hot weather and to improve the ventilation levels. However, the main cooling systems used in UAE as of current time to achieve the high level of indoor comfort are the air condition systems employing advanced and mechanical cooling systems, such systems have been implemented based on the influence of many factors such as the discovery of oil, integration of electricity and advanced cooling technologies. In order to show modernity, the separated houses, and facade with glazing were extensively used which increased significantly the rate of thermal gain due to the insufficient building's insulation and due to more exposure to sun radiation, such scenario, in turn, led to more heat gains, and more cooling energy consumption. On top of that, the energy prices in the region are relatively very cheap; this situation has encouraged the integration of cooling systems that featured with high energy consumption in the buildings. This research has followed hybrid approach by implementing two passive cooling strategies namely the insulation in the external walls and the integration of Green roof as well as one active strategy which is basically the employment of a PV panel to generate clean energy. The results showed good energy savings. Adding the Polyurethane Board $(6.3 \mathrm{~cm})$ insulation to the external wall managed to reduce the thermal transmittance from $1.65\left(\mathrm{~W} / \mathrm{m}^{2} . \mathrm{K}\right)$ to $0.32 \mathrm{~W} / \mathrm{m}^{2} . \mathrm{K}$, by which Estidama 1 pearl requirement has been fulfilled and the cooling power reduction was in the range of $8.8 \%$. In the meantime, the integration of the green roof managed to reduce the thermal transmittance from $0.4812\left(\mathrm{~W} / \mathrm{m}^{2} . \mathrm{K}\right)$ to $0.1982\left(\mathrm{~W} / \mathrm{m}^{2} . \mathrm{K}\right)$ and was successful to reduce the cooling power consumption to a value of $2.94(\mathrm{MWh})$ that is $3.7 \%$ of total annual cooling energy consumption in the Villa. Lastly the study has demonstrated also the installation of PV panel that is composed of 53 units type poly-Si PLUTO245 - occupying 87 meter squared managed to generate approximately annual power of 22 (MWh), 10.16 (MWh) was delivered to the load and $11.94(\mathrm{MWh})$ was exported to the grid, 5.08 (MWh) was consumed by the AC system, this value forms a power saving of $6.4 \%$ of the total power consumed by the AC system. As an overall, the bundle of three strategies has proved its efficiency to reduce the cooling energy consumption and to enhance the energy efficiency in the 
residence. The total power consumption saving was with a value of $15.45(\mathrm{MWh})$ and with a percentage of $19.6 \%$ of the total cooling power consumption in the Villa.

\section{References}

[1] J. Kreider, A. Rabl, P. Curtiss, Heating and cooling of buildings. New York: McGraw-Hill, 1994.

[2] H. Al-Hinai, W. Batty, S. Probert, "Vernacular architecture of Oman: Features that enhance thermal comfort achieved within buildings," Applied Energy, vol. 44, no. 3, pp. 233-258, 1993.

[3] E. Kkalaf Aljofi, "The Measures of Light Performance of Wind Catchers in Hot Climatic Zones," IJET, vol. 8. no. 1, pp. 45-49, 2016.

[4] N. Majid, H. Shuichi, N. Takagi, "Vernacular Wisdom: The Basis of Formulating Compatible Living Environment in Oman," Procedia - Social and Behavioral Sciences, vol. 68, pp. 637-648, 2012.

[5] H. Taleb, "Using passive cooling strategies to improve thermal performance and reduce energy consumption of residential buildings in U.A.E. buildings," Frontiers of Architectural Research, vol. 3, no. 2, 2014.

[6] Indexmundi.com. (2016). Electricity consumption per capita - Country Comparison, [Online]. Available: http://www.indexmundi.com/g/r.aspx?t=0\&v=81000\&l=en

[7] C. Alalouch, M. Saleh, S. Al-Saadi, "Energy-Efficient House in the GCC Region," Procedia - Social and Behavioral Sciences, vol. 216, pp. 736-743, 2016.

[8] L. Perez-Lombard, J. Ortiz, C. Pout, "A review on buildings energy consumption information," Energy and Buildings, vol. 40, no. 3, pp. 394-398, 2008.

[9] P. Bevilacqua, D. Mazzeo, R. Bruno, N. Arcuri, "Experimental investigation of the thermal performances of an extensive green roof in the Mediterranean area," Energy and Buildings, vol. 122, pp. 63-79, 2016.

[10] A. Palmero-Marrero, A. Oliveira, "Effect of louver shading devices on building energy requirements," Applied Energy, vol. 87, no. 6, pp. 2040-2049, 2010.

[11] H. Taleb, S. Sharples, "Developing sustainable residential buildings in Saudi Arabia: A case study," Applied Energy, vol. 88, no. 1, pp. 383-391, 2011.

[12] X. Gong, Y. Akashi, D. Sumiyoshi, "Optimization of passive design measures for residential buildings in different Chinese areas," Building and Environment, vol. 58, pp. 46-57, 2012.

[13] M. Mandalaki, K. Zervas, T. Tsoutsos, A. Vazakas, "Assessment of fixed shading devices with integrated PV for efficient energy use," Solar Energy, vol. 86, no. 9, pp. 2561-2575, 2012.

[14] P. Shaikh, N. Nor, P. Nallagownden, I. Elamvazuthi, "Intelligent multi-objective optimization for building energy and comfort management," Journal of King Saud University - Engineering Sciences, 2016.

[15] E. Fenton. (2011). Active systems to reduce energy use. [Online] Architecture AU. Available: http://architectureau.com/articles/active-systems/

[16] Guide2dubai.com. (2015). DEWA Bills in Dubai - Water and Electricity Cost. [Online]. Available: http://www.guide2dubai.com/living/expat-life/dewa-utility-bills

[17] N. Al Badri, "Grid electricity Demand Reduction through Applying Passive and Active Strategies for a House in Baghdad, Iraq," M.S. thesis, British University in Dubai, 2013.

[18] Mohamed Bin Rashid Al Maktoum Solar Park. (2016). Dubai: Dubai Electricity and Water Authority, (1st ed.) [Online]. Available at: https://www.dewa.gov.ae/ar-AE 